\title{
ALLOCATING PRIORITY BETWEEN OPEN-END MORTGAGES AND FEDERAL TAX LIENS: A SUGGESTED MODIFICATION OF THE ABA PROPOSAL
}

IN the past fifteen years the open-end mortgage has come into use as a means of financing the purchase of private homes. ${ }^{1}$ This device enables the home owner to finance future home improvements without incurring either the high interest costs and larger payments incident to short term financing, ${ }^{2}$ or the higher interest rates of a second mortgage. ${ }^{3}$ An open-end mortgage provides that future loans may be made on the same security as the original loan, and may be repaid over the life of the mortgage at the same low interest rates charged in the original mortgage. 4 At the same time, the mortgagor avoids paying interest on an excessive initial loan for which he has no immediate use. ${ }^{5}$ This device is equally attractive to mortgage lenders, since its low cost to borrowers encourages a sizeable increase in the total volume of home improvement loans, ${ }^{6}$ from which the initial lender will benefit. The lender also saves the expense of an additional credit investigation since he is

1. The open-end device has long been used in construction mortgages. See, e.g., Stephens v. Ahrens, 179 Cal. 743, 178 Pac. 863 (1919) ; Nussenfeld v. Smith, 110 Conn. 438, 148 Atl. 388 (1930). By lending further amounts as the construction progresses, mortgagees can avoid advancing amounts in excess of the value of the unimproved or partially improved land and thereby assure themselves of adequate security to cover the total amount of the loan at all times. Osborne, Mortgages 277 (1951) [hereinafter cited as Osbonne]. See generally Blackburn, Mortgages to Secure Future Advances, $21 \mathrm{Mo}$. L. Rev. 209 (1956); Note, Mortgages Securing Future Advances, 8 Texas L. Rev. 371 (1930); Note, 38 MrNN. L. Rev. 507 (1954).

2. Since the open-end device allows repayment of subsequent advances to be spread out over the remaining life of the mortgage, the individual payments will naturally be smaller than those in which the sum must be repaid over a relatively short time. See The "Open End" Mortgage, Architectural Forum, June 1949, p. 102; House \& Home, Aug. 1952, p. 59; Note, 38 MrNn. L. Rev. 507, 508 n.4 (1954). A three year loan with interest at $91 / 2 \%$ involves monthly payments of about $\$ 30.00$ per $\$ 1,000$, as compared with about $\$ 10.00$ on a ten year loan at $4 \mathrm{t} / 2 \%$ interest under an open-end mortgage. Fortune, Sept. 1949 , p. 18.

3. OSBORNE 276.

4. The interest rate may be as little as one-half that of even the most favorable short term loans. See House \& Home, Aug. 1952, p. 59. In addition, the lender may agree to extend the life of the mortgage, thereby providing more time for repayment and reducing the size of the payments still further. See Note, 38 MrNw. L. REv. 507, 508 n.4 (1954).

5. See OsBorNe 276. While the excess amount could, with some effort, be reinvested until needed, it is unlikely that the interest being paid to the lender could be recouped fully by the borrower unless he resorted to speculative investments that may be inconsistent with his financial position. Ibid.

6. One commentator feels that full use of the open-end mortgage in the home financing field alone would double or triple the annual outlay for home improvements. The "Open End" Mortgage, Architectural Forum, June 1949, p. 102. 
already familiar with the borrower's financial status. ${ }^{7}$ Moreover, because the buyer looks to him for subsequent advances, the mortgagee is able to safeguard his investment by advising the borrower against overextending his credit position. ${ }^{8}$

One factor which contributes to the low cost of the open-end mortgage is the rule in most jurisdictions which gives the mortgagee's lien priority over third party security interests arising after the execution of the original mortgage but prior to the making of future advances. A few states regard each advance as consideration for a new promise to repay the advance, thus treating each transaction as a separate mortgage. ${ }^{9}$ But the more widely accepted view assumes that the obligation secured by the mortgage is the mortgagor's promise to repay all sums advanced to him then or later under the terms of the mortgage. ${ }^{10}$ Thus the lien on the secured property arises at the time of the execution of the original mortgage agreement, ${ }^{11}$ and the fact that the total amount of the obligation is uncertain is held not to detract from the "perfection" of the security interest at that time. ${ }^{12}$ Under the rule of "first in time is first in right," intervening third party liens are subordinated to the mortgagee's lien for all advances regardless of when the advances are made. Only if the mortgagee has actual knowledge of an intervening interest will his lien be subordinated to such interest. ${ }^{13}$ This assurance of priority eliminates the

7. Ibid.

8. See id. at 104; House \& Home, July 1952, p. 80.

9. See, e.g., Ter-Hoven v. Kerns, 2 Pa. 96, 99 (1845); Spader v. Lawler, 17 Ohio 371 (1848) ; Ladue v. Detroit \& M.R.R., 13 Mich. 380 (1865); OsBorne $\$ \$ 114,117$.

10. Ibid.; 4 PoMeroy, EQuity JURISPRUdence 594 n.17 (5th ed. 1941); see Comment, Mortgages to Secure Future Advances, 23 TENN. L. Rev. 195, 198 (1954).

The rule in some jurisdictions is statutory. See statutes cited notes 35-37 infra.

11. Osborne § 114; PoMeroy, op. cit. supra note 10, at $594 \mathrm{n} .17$; Note, 6 VA. L. Rev. 280, 282 (1920).

12. McDaniels v. Colvin, 16 Vt. 300, 302 (1844); see Robinson v. Williams, 22 N.Y. $380,384-85$ (1860).

13. See, e.g., Elmendorf-Anthony Co. v. Dunn, 10 Wash. 2d 29, 116 P.2d 253 (1941); Williams v. Gilbert, 37 N.J. Eq. 84 (1883); Ackerman v. Hunsicker, 85 N.Y. 43 (1881); Annot., 138 A.L.R. 566, 568-76, 579-87 (1942); ConN. GEN. Stat. § 49-2 (1958). It is occasionally held that even the mortgagee's actual knowledge of the intervening interest is not sufficient unless the intervening claimant has actually made specific objection to the advances. See Patch \& Co. v. First Nat'l Bank, 90 Vt. 4, 96 Atl. 423 (1916); McDaniels v. Colvin, 16 Vt. 300,302 (1844).

In some states, constructive notice is sufficient. See Annot., 138 A.L.R. 566, 587-89 (1942); OsBoRne 293 n.47 (citing cases). This extension of the notice rule, however, is simply a circular way of saying that intervening security interests, when recorded, take priority over subsequent advances-the minority rule.

If, by the terms of the mortgage, the advances are obligatory, they take priority over such intervening third-party interests even if there has been actual notice. This rule applies even in jurisdictions which do not recognize the priority of optional advances. See, e.g., Kuhn v. Southern Ohio Loan \& Trust Co., 101 Ohio St. 34, 126 N.E. 820 (1920). Optional advances made to preserve the security or to prevent loss through bankruptcy are -ordinarily treated as obligatory. See, e.g., Cedar v. W. E. Roche Fruit Co., 16 Wash. 2d 652, 663-64, 134 P.2d 437, 442 (1943); Hamilton v. Rhodes, 72 Ark. 625, 628,83 S.W. 351, 352 (1904). 
necessity and expense of searching the record each time an advance is made. ${ }^{14}$ If such searches were necessary, the cost of open-end mortgages might be as great as ordinary short-term financing. ${ }^{15}$ The cost advantage is particularly significant when small sums are advanced, since the cost of searching the record, a fixed amount, becomes a proportionally larger part of the total financing cost as the amount of the loan decreases.

The federal tax collector, however, is presently threatening to negate the cost-reducing effect of the state priority doctrine. Recent judicial and administrative declarations indicate that a lien for unpaid federal taxes, which attaches to "all property"10 of the taxpayer, will take priority over advances under an open-end mortgage made after the tax lien has been recorded, even though the mortgagee has no actual notice of the tax lien. ${ }^{17}$ The federal tax lien serves as a means of securing tax claims against delinquent taxpayers. ${ }^{18}$ It arises upon assessment of the tax but must be recorded to be effective against a "mortgagee, pledgee, purchaser, or judgment creditor."19 Federal courts have claimed the right to determine priority of federal liens without

14. This, of course, is not true in the few states that require only constructive notice of intervening security interests. There, a search is required to determine if there are any intervening liens of record. Ellery, Open End Mortgages, Title News, July 1953, p. 12, at 20. Local statutes occasionally give a specific class of liens, such as mechanics' liens, priority over other liens under certain circumstances regardless of when they arise. In such a case, a record search by the mortgagee would be advisable in spite of the actual notice rule. See McGuyre v. Duncan, 100 Okla. 217, 229 Pac. 199 (1924). Frequently, however, such lienors will nevertheless be required to give actual notice to mortgagees in order to obtain priority over future advances made under an open-end mortgage. See, e.g., Kingsport Brick Corp. v. Bostwick, 145 Tenn. 19, 235 S.W. 70 (1921).

15. A title search may cost as much as $\$ 125$ in New York City. Fortune, Sept. 1949, p. 18. See generally McWilliams \& Foster, A Discussion of Open-End Mortgages, Title News, July 1956, p. 10. Open-end mortgages are less frequently used in minority-rule jurisdictions such as Pennsylvania where a title search is necessary before advances are made. Ellery, Open End Mortgages, Title News, July 1953, p. 12, at 14; see House \& Home, July 1952, p. 80.

16. If any person liable to pay any tax neglects or refuses to pay the same after demand, the amount ... shall be a lien in favor of the United States upon all property and rights to property, whether real or personal, belonging to such person.

InTr: Rev. Code of 1954, § 6321; see Glass City Bank v. United States, 326 U.S. 265 (1945). .

17. United States v. Christensen, 269 F.2d 624 (9th Cir. 1959); United States v. Ringler, 166 F. Supp. 544 (N.D. Ohio 1958) ; Metropốlitan Life Ins. Co. v. United States, 60-1 U.S. Tax Cas. 89133 (N.Y. Sup. Ct., App. Div. 1959); Rev. Rul. 56-41, 1956-1 Cum. Burc. 562. See generally Plumb, Federal Tax. Collection and Lien Problenis, 13 TAx L. Rev.' 247, 459 (1958); Kennedy, The Relative Priority of the Federal Governmcnt: The Pernicious Career of the Inchoate and General Lien, 63 YALE L.J. 905 (1954).

18. See generally Reid, Tax Liens, Their Operation and Effect, N.Y.U. 9xH IssT. on FED. TAX 563 (1951).

19. INT. Rev. CoDE of 1954, § 6323(a); see United States v. Cargill, 218 F.2d 556 (1st Cir. 1955) ; Maryland Cas. Co. v. Charleston Lead Works, 24 F.2d 836, 838 (E.D. S.C. 1928). 
regard to state law. ${ }^{20}$ Under federal law, a prior private lien will take priority over a recorded federal tax lien only if it is "choate"-that is, definite as to the identity of the lienor, the property to which the lien attaches, and the amount of the debt. ${ }^{21}$ Observing that the amount to be advanced under the usual open-end mortgage is uncertain, the Service has ruled that the mortgagee's lien is not fixed, specific, or perfected under federal law until the advance is actually made, ${ }^{22}$ and is therefore "inchoate" until that time. Thus tax liens, once recorded, are prior to any advance subsequently made. ${ }^{23}$ Consequently, mortgagees who had previously felt reasonably safe in advancing additional sums to borrowers without searching the record must now incur the expense of such a search to guard against intervening tax liens. ${ }^{24}$ This extra cost may increase the financing charge of future advances to a point where the open-end mortgage loses its attractiveness and utility. ${ }^{25}$

20. [T] he effect of a lien in relation to a provision of Federal law for the collection of debts owing the United States is always a Federal question. Hence, although a state court's classification of a lien as specific and perfected is entitled to weight, it is subject to reexamination by the courts.

Rev. Rul. 56-41, 1956-1 Cum. BucL. 562-63; see United States v. Acri, 348 U.S. 211 (1955) ; United States v. Security Trust \& Sav. Bank, 340 U.S. 47, 49 (1950).

21. United States v. City of New Britain, 347 U.S. 81, 84 (1954); United States v. Security Trust \& Sav. Bank, 340 U.S. 47 (1950); United States v. Waddill, Holland \& Flinn, Inc., 323 U.S. 353, 358-59 (1945) ; see Glass City Bank v. United States, 326 U.S. 265 (1945).

For a discussion of recent Supreme Court per curiam decisions which raise doubts as to the continued adherence to the definition articulated in these cases, see Brown, Foreword: Process of Lawe, 72 HARv. L. REv. 77, 82-87 (1958). The author concludes, however, that the decisions may be interpreted as definitions of the status of mechanics' liens, id. at 87 , and thus do not effect the status of advances actually made, which are mortgages already governed by INr. REv. CoDE of 1954, § 6323(a), United States v. Ringler, 166 F. Supp. 544 (N.D. Ohio 1958). See note 19 supra.

22. Rev. Rul. 56-41, 1956-1 Cun. Bull. 562, 563 ("it is possible that no future advances may ever be made").

23. United States v. Christensen, 269 F.2d 624 (9th Cir. 1959); Note, 27 Forderax L. REv. 284 (1958). The Treasury's statement, supra note 22, implies that if the future advances are obligatory, and thus specific, they may prevail over an intervening federal $\operatorname{tax}$ lien. A subsequent, unpublished ruling, A-619373, issued Aug. 24, 1956, stated that the earlier ruling was not intended to apply to advances definitely contracted for and required to be made under the terms of the mortgage. See Prather, Federal Liens as They Affect Mortgage Lending, 13 Bus. Law. 118, 122-23 (1957). Under state law, such obligatory advances are usually given priority over earlier third party liens regardless of notice. See note 13 supra. However, a subsequent Supreme Court decision has cast considerable doubt on the validity of this ruling. United States v. R. F. Ball Constr. Co., 355 U.S. 587 (1958) ; see ABA, Final Report of the Commitree on Federal Liens 14-15 (1959) [hereinafter cited as ABA Report]. See generally Note, 43 Mrnn. L. Rev. 755 (1959).

24. See Schurch, The Private Lien Holder and Your Uncle Sam, Title News, June 1958, p. 16.

25. See note 15 stpra. This problem would be even more acute were it not for the fact that mortgagees need search the record only as far back as the date of the last search under the same mortgage. See Note, 65 HARv. L. REv. 478, 488 (1952). 
Although in most jurisdictions application of the "choateness" principle to open-end mortgages gives the Government a priority advantage not available to other intervening creditors, the advantage seems justified. Priority doctrines in this area are ultimately based on a determination that one of two parties should be required to make a record search to determine his priority status. Since most intervening security interests will be created by lenders, and since most lenders will make a title search of the property they are planning to accept as security (and will thus discover any open-end mortgages), it is commercially more reasonable to require the intervening lender to take the extra step of giving the mortgagee actual notice of his lien. ${ }^{26}$ The balance of convenience favors the mortgagee, because otherwise he would be burdened with making a record search before each advance. When a federal tax lien is involved, however, the balance shifts. Unlike an intervening lender who would want to make a record search before lending, the Government finds that because of unpaid taxes it is already a creditor. Therefore, it has no occasion to search the record, particularly since its lien attaches to all property of the taxpayer. If the Government were made subject to the majority rule, it would have to search the record and notify mortgagees in order to protect against erosion of its security by future advances. In view of the large volume of tax liens, this requirement would impose an enormous expense and administrative burden on the Government's tax collection procedures. ${ }^{27}$

Nevertheless, the Government's convenience is served only at the expense of some loss in the usefulness of the open-end mortgage. Regardless of his continued priority over private creditors, the open-end mortgagee must now search to protect against intervening tax liens. In an effort to reconcile the interests of the Government and mortgagees, the American Bar Association's Committee on Federal Liens has proposed an amendment of the Internal Revenue Code which would allow lenders to record their mortgages with the District Director of Internal Revenue and in turn would require the Director to notify mortgagees of record when a tax lien is filed. ${ }^{28}$ Until notified, the lender could safely advance additional sums to his borrowers, ${ }^{29}$ and so would

26. See Osborne § 119; Blackburn, supra note 1, at 230; ABA REPORT 15.

27. ABA REPORT 15-16, 88. For the contrary view, that federal tax liens should take their place with other private liens under state priority laws, see Prather, supra note 23, at 124; Plumb, Effect on Banks and Secured Lenders of Federal Tax Lien Proposals, 14 Bus. LAw. 782 (1959).

28. Ibid. See proposed $\S 6323(a)(2)$ (E) in ABA REPORT 66, discussed in Plumb, supre note 27 , at 786 . The proposal would make recording optional with the lender in case he felt that recording would be undesirable because, for example, it might evoke tax lien action by the Internal Revenue Service. Such a lender would then, of course, have to rely on his own record search to determine the priority status of the proposed advance. Ibid.

The proposal also deals with other conflicts between state law and the federal priority rule, such as the apparent priority of federal liens over obligatory advances. See notes 13,23 supra. The ABA proposal would give obligatory and "necessary" advances priority. Id. at 15,65 .

29. ABA REPORT at 66 . 
be relieved of the necessity and cost of making a record search before each advance. The Government, on the other hand, would have a simple method of discovering and notifying parties with an interest in a specific taxpayer's property. This proposal is currently before Congress. ${ }^{30}$

Although the ABA proposal does retain some of the cost advantages of the open-end mortgage, it does not preserve those advantages in the area where the open-end mortgage is perhaps most useful-the small advance to the mortgagor for home improvements. The ABA draftsmen have recognized that a filing fee will be required to offset the substantial cost to the Revenue Service of maintaining and searching such a file and notifying mortgagees. ${ }^{31}$ Since the procedure contemplated requires a search through the Government's files each time a tax lien is recorded, the amount of the fee may approach the cost of a record search. Of course, if the home-owner plans to borrow funds several times in the future, the cost of the initial filing fee, which is nonrecurring, can be spread over the many later transactions, and the lower cost of open-end mortgage advances may still obtain. But since many mortgagors do not know whether they will ever use the open-end feature of their mortgages, paying the filing fee at the time the original mortgage is executed will be a waste of money. For these mortgagors, the question of whether or not to pay the filing fee will arise only when an advance is actually asked for. Filing when the advance is actually sought would act both as a search for past tax liens and as protection for future advances. Even at this time, however, the probability that further advances will be needed is not great; thus the cost of the filing fee would have to be considered as a cost of financing this loan alone. While the fee may be insignificant to borrowers of large sums because it is proportionally a very small part of the total interest payment, the fee may raise the total financing cost of small advances enough so that the borrower would find it no more expensive to pay the higher interest rates of short-term unsecured financing. ${ }^{32}$ Since any expense, even a small one, will be a significant addition to the interest cost on a small advance, there is no way to protect the small borrower, short of eliminating the proposed fee or requiring the government to make a title search and give actual notice to open-end mortgagees. Congress must simply choose between the competing interests.

A modification of the ABA proposal, however, would enable Congress to favor the small borrower without altogether sacrificing the priority of tax

30. The ABA proposal was introduced in the 86th Congress, 1st Session as S. 2305 on June 30,1959 , and as H.R. 7914, 7915 on June 23, 1959. The bills were referred to the Senate Finance Committee and the House Ways and Means Committee respectively. 105 CoNG. Rec. 11679, 12186 (1959).

31. The amount of the fee would, under the proposal, be prescribed by the Treasury. Id. at $88-89$.

32. The ABA proposal is intended to revamp the entire field of tax liens and is not limited to dealing with the specific problem of the cost of record searching. Consequently, there is no estimate made of the relatively small issue of the fee's size or its effect on open-end mortgages. 
liens which ordinarily obtains under the "choateness" doctrine. Future advances under open-end mortgages could be given priority over tax liens recorded before the advance was made, ${ }^{33}$ but only up to a specified amount; above that limit, tax liens would take priority according to the recordation and notification provisions of the proposal. Thus, borrowers whose future advances totaled less than the specified amount would be spared the expense of the filing and notification fee. Above this amount, it would be necessary to file with the District Director and pay the requisite fee. ${ }^{34}$ This proposal would accord with some state statutory provisions which give absolute priority, regardless of notice, to advances up to a certain limit. Some of the statutes expressly limit priority to advances for the purpose of repair, alteration, or improvement of the mortgaged property, ${ }^{35}$ which suggests that the policy underlying such statutes is the state's interest in promoting private maintenance and improvement of the community's business and residential facilities. Congress, in providing for the limited grant of priority, would ensure that the federal lien law did not impinge upon this state policy.

In determining the amount to be given priority, Congress would have to strike a balance between providing a large enough supply of inexpensive credit to meet the needs of the home owner ${ }^{36}$ and preserving the efficacy of

33. Actual notice of the tax lien would, of course, destroy the priority of the small advance. Thus, if a lender, in filing the mortgage to secure a large advance, is notified by the Service's record office that a tax lien has already been recorded against the mortgaged property, he could not then advance a smaller amount, within the limit, and have that smaller amount take priority over the tax lien.

34. The lender could exercise the option of not filing if he so desired.

One objection to creating an absolute priority for the benefit of the small borrower would be the fact that the Government's interest would be subordinated to the minimum amount in all cases, whether the advance is large or small. For example, if the limit is $\$ 2,000$, a lender who, without filing, advances $\$ 50,000$ to the mortgagor could still claim priority for $\$ 2,000$ of that advance. No policy is served by allowing the priority in this case, because it does not make the cost of financing significantly less. But the likelihood that absolute priority will be abused in this way seems minimal; banks or other open-end mortgagees will maintain control of the total amount advanced and will probably not advance amounts above the priority limit without first filing to secure their interest; and if their interest cannot be secured, they will not lend on the terms of the mortgage.

35. Mass. Ann. Laws ch. 183, §.2SA (Supp. 1959) (“. . for repairs, improvements or replacements to ... the mortgaged premises . . . "); MD. ANN. CoDE art. 66, \& 2 (1957) (" for paying the cost of any repair, alterations or improvements to the mortgaged property"). The purpose of granting absolute priorify for a limited amount is to give borrowers a certain degree of flexibility in borrowing smaller amounts. $\mathcal{C}$. 'Blackburn, supra note 1 , at 232.

36. One state has recently raised the statutory limit from $\$ 500$ to $\$ 1,500$, apparently to adjust to rising costs of living. MD. ANN. CoDE art. 66, $\$ 2$ (1957); see Blackburn, stipra note 1 , at 232 .

It should be recognized that the amount of the exemption required to provide an adequate fund for home improvement might, if borrowed at one time, be large enough to render the filing fee an insignificant cost; this suggests that home improvement loans can be made almost as cheaply as before. But it is unrealistic to expect the borrower to use the entire fund at one time. Borrowing can be expected to occur sporadically and in small 
the Government's tax collection procedures. The tax collector cannot be expected to search the public records for the purpose of notifying mortgagees who have not filed with the District Director; if public searches must be made, the entire purpose of the ABA's proposed filing system would be defeated. Therefore, the Government would have to accept a subordinate position to any advance which is below the exempt amount, a factor which dictates keeping the exemption as small as possible.

The limitation provisions of state statutes in this area might serve as a guide in striking this balance. Some statutes allow priority to any advance as long as the advance does not bring the total debt outstanding above the original amount of the mortgage. ${ }^{37}$ Under this method, however, the limit would vary in accordance with the portion of the original mortgage that has been paid up, and thus would bear no relation to the policy sought to be implemented. For example, the mortgagor may find within a few months of the execution of the mortgage that a large amount of repairs are necessary, costing much more than the amount by which the original mortgage debt has been reduced. Or, if no repairs are needed until after the mortgage is largely paid off, the size of advances which could be made without filing would probably be much larger than needed. The latter objection is met by some statutes which provide that even if the advance does not exceed the original debt limit, it also cannot exceed a certain dollar amount. ${ }^{38}$ But since this formula also prevents an increase in the original debt, it too fails to provide for loans which become necessary shortly after the mortgage is executed. This objection might not weigh too heavily, since many immediate needs can be foreseen and thus provided for in the original mortgage. Nevertheless, if Congress wishes to meet this objection, it can look to a third variety of statute which sets only a specific dollar limit, regardless of whether or not the advance raises the outstanding debt above the amount of the original debt. ${ }^{30}$ Which of these methods Congress chooses will, of course, ultimately depend on the degree to which Congress wishes to extend the policy of providing inexpensive homeimprovement credit at the expense of the tax collector.

amounts. Furthermore, the borrower is still not likely to know at the time of making the loan whether he will ever need another.

37. See Mass. Ann. Laws ch. 183, § 28A (Supp. 1959).

38. See MD. ANN. CoDE art. 66, § 2 (1957).

39. See R.I. Gen. LAws Ann. \& 34-25-1 (1956) (\$ 34-25-3 excepts attachments, executions, and lis penders which occur after execution of the mortgage but prior to the future advances). 